\title{
Financial Neoliberalism and Exclusion with and beyond Foucault
}

\section{Tim Christiaens}

KU Leuven

\begin{abstract}
In the beginning of the 1970s Michel Foucault dismissed the terminology of 'exclusion' for his projected analytics of modern power. This rejection has had major repercussions on the theory of neoliberal subject-formation. Many researchers disproportionately stress how neoliberal dispositifs produce entrepreneurial subjects, albeit in different ways, while minimizing how these dispositifs sometimes emphatically refuse to produce neoliberal subjects. Relying on Saskia Sassen's work on financialization, I argue that neoliberal dispositifs not only apply entrepreneurial norms, but also suspend their application for groups that threaten to harm the population's profitability. Neoliberal dispositifs not only produce entrepreneurial subjects but also surplus populations that are expelled from the overall population to maintain its productivity. Here, the concept of 'exclusion' is appropriate if understood in Agamben's sense of an inclusive exclusion. The surplus population is part of neoliberal dispositifs, but only as the element to be abandoned.
\end{abstract}

\section{Keywords}

exclusion, finance, Foucault, neoliberal subjectivity, neoliberalism, Sassen

When arguing about the impact of neoliberalism on subjectivity, Foucault's 1979 lectures on The Birth of Biopolitics (2008) set the standard. Although Reagan and Thatcher had not yet come to power, the liberalization of finance had only started, and the welfare state seemed to many untouchable; Foucault's lectures proved premonitory. His central argument was that today's dominant form of governmentality focuses on the production of subjects as entrepreneurs of their human capital by establishing competition. Foucault's legacy can consequently be gauged by the frequency with which neoliberal dispositifs are equated with power-relations that produce entrepreneurial behaviour via competition 
(McNay, 2009: 56; Dardot and Laval, 2013: 259; Lazzarato, 2015: 14-15; Brown, 2015: 22; Bröckling, 2016; Davies, 2017: 199-200). For many researchers, "the neoliberal subject is an entrepreneur of herself' (Lorenzini, 2018: 8). Neoliberalism appears as the generalized entrepreneurialization of subjectivity.

Is there a way to think about exclusion with such an emphasis on entrepreneurialization? Foucault's lectures have induced a widespread suspicion toward the terminology of 'exclusion' in theories of neoliberal subjectivity-formation. Foucault himself had rejected the term in his Collège de France lectures of 1973 (2015: 2-5; Elden, 2017: 85-7). It thus no longer appeared prominently in his subsequent writings. Later researchers following in Foucault's footsteps have received Foucault's suspicion toward exclusion in three ways: a first group accepts and repeats Foucault's silence on exclusion in neoliberalism (Read, 2009; McNay, 2009; Bröckling, 2016), a second group reinserts it, relying on other writings of Foucault on thanatopolitics and state racism (Mbembe, 2003; Esposito, 2008; Willse, 2010), and a third group uses Foucault's suspicions to develop a new understanding of exclusion (Lazzarato, 2009; Mezzadra and Neilson, 2013; Brown, 2015). The latter group attempts 'to move beyond the binary inclusion/exclusion, pointing to the proliferation of [...] subjectivities that are neither fully insiders nor fully outsiders' (Mezzadra and Neilson, 2012: 62). ${ }^{1}$ They have described this approach under many different names: I will use Lazzarato's term 'differential management of inequalities' (Lazzarato, 2009: 118), but they also call it 'disaffiliation' (Castel, 2009), 'precarization' (Lorey, 2015), 'differential inclusion' (Mezzadra and Neilson, 2013), 'management and hierarchization of differences' (Hardt and Negri, 2000: 199), etc. What in everyday discourse passes for 'exclusion' can, in their view, more accurately be described as an assemblage of strategies that allot different sections of the population to variegated regimes of practices. Depending on how well individuals have internalized entrepreneurial norms, they are inserted into different regimes of practices. These researchers do not deny the existence of genuine forms of exclusion but argue that, in many cases, differential management of inequalities would be a more fitting description.

Because of the stress on the differential management of inequalities, I argue that the theory of neoliberal subjectivity-formation lacks a good framework for forms of exclusions that do not fit this model, especially in the realm of finance, which tends to exclude people from its operations when they are no longer valuable to shareholders. I propose to use Saskia Sassen's theory of expulsion to amend this gap. According to Sassen, finance's 'surplus populations' (Sassen, 2016: 90) are collateral damage that should allegedly be abandoned in the name of the optimization of the population as a whole. ${ }^{2}$ From this perspective, neoliberal powerrelations cannot be equated with dispositifs that differentially produce 
entrepreneurial subjects. Neoliberal government also maintains regimes of practices that render subjects invisible and ungoverned. It sometimes abandons those who cannot contribute to the vitality of the population.

I will first outline why Foucault dismisses the terminology of 'exclusion' in 1973 and how this impacts his own writings on neoliberalism. Foucault uses it prolifically before 1973, but rejects it in The Punitive Society for being too abstract and wrongly suggesting that societies have insides and outsides. He consequently thinks of neoliberal governmentality as a system that potentially includes all aspects of life into the project of entrepreneurialization. Secondly, I show how this impacts subsequent theories of neoliberal subjectivity-formation. Though there are exceptions, the dominant approach reinterprets exclusion as forms of differential management of inequalities. The latter purportedly constitutes a differentiated patchwork of dispositifs that induce individuals to act as entrepreneurs with varying degrees of invasiveness. In the third section, I give two examples of forms of exclusion that cannot be reinterpreted as strategies of differential management, namely the 'management by terror' practiced at France Télécom and the environmental side-effects of GDP measurements in the city of Haina, Dominican Republic. Fourthly, I use Agamben's notion of abandonment to describe these examples as cases where neoliberal norms of entrepreneurship are not applied - not even as a form of differential management - but suspended. The model of differential management does not deny this in principle, but does not provide any coordinates for explaining such suspensions of the application of entrepreneurial norms. I subsequently introduce Sassen's theory of financial expulsion $(2010,2014)$ to update Foucault's analytics of neoliberal governmentality. By prioritizing the interests of shareholders and by extracting value from non-financial forms of wealth-creation until resources are depleted, the financial system tends to expel surplus populations.

\section{Foucault's Rejection of the Terminology of 'Exclusion'}

Before 1973 Foucault frequently uses the terminology of 'exclusion' to describe the effects of power in modern society (Foucault, 2015: 17n6; Gordon, 2013), but exactly when the concept reaches the height of its popularity in France with René Lenoir's Les Exclus (1974), Foucault rejects it in The Punitive Society (2015: 2-5) for two reasons:

(a) He firstly finds the terminology of exclusion 'too broad and, above all, composite and artificial' (Foucault, 2015: 2). As Allen (2013: 343) highlights, in the first half of the 1970s Foucault takes a critical distance from his early work's sole emphasis on discursive representations by looking at the larger dispositifs in which these representations participate. Studying, for instance, the history of madness requires not only archaeologies of how societies discursively frame 'madness', but also 
investigations into how concrete regimes of practices intervene in the lives of people to produce the realities designated by discourses about madness. Discourses are embedded in regimes of practices that also contain non-discursive elements (Dean, 2009: 27; Elden, 2016: 53). The term 'exclusion', however, risks ignoring the latter. It functions as a catch-all term for variegated social phenomena that have no shared underlying regimes of practices. The exclusion of, for instance, the mad is not necessarily situated in the same regimes of practices as the exclusion of young banlieusards. On the level of discourse one might hence represent both as 'excluded', but putting these different issues under a single header obscures more than it enlightens about the local power-relations at work in psychiatry or the banlieues. Foucault thus rejects the artificial and abstract term 'exclusion' in favour of an approach more sensitive to concrete regimes of practices.

(b) Observing these concrete regimes of practices, Foucault secondly rejects any clear-cut opposition between exclusion and inclusion. There is no such thing as being 'outside' of society. The myriad of psychiatric institutions are, for instance, frequently viewed as excluding the insane, but a more truthful account would point to its strategy of normalization and rehabilitation. Psychiatric institutions create discursive rationalities and non-discursive techniques that re-introduce psychologically challenged individuals into 'normal' society as docile bodies. The insane are not 'excluded', but temporarily marginalized in a specific disciplinary institution to re-educate them.

Foucault builds on these insights an analytics of power that culminates most explicitly in The Subject and Power (2000: 340):

In effect, what defines a relationship of power is that it is a mode of action that does not act directly and immediately on others. Instead, it acts upon their actions: an action upon an action, on possible or actual future or present actions.

Power is a 'conduct of conducts' (Foucault, 2000: 341). It manipulates subjects' field of possible actions in order to stimulate them to perform the right kind of actions while discouraging them from actualizing undesirable potencies. This perspective focuses on how power and knowledge produce certain subjectivities and less on how people could be 'excluded' from such processes of subject-formation. This is not surprising given that Foucault's primary aim is to show how the production of subjectivity via power and knowledge intersects with the subject's freedom. Governmental interventions do not exhaustively determine subjectivity, but make particular regularities more or less likely by using knowledge about the population to adjust free subjective behaviour in conformity with governmental objectives (Dean, 2009: 21-4). This persistence of subjective freedom opens the door for resistance, or counter-conducts 
(Foucault, 2007: 191-216). If power depends on the population's selfconducts, subjects possess the autonomy to escape governmental objectives. They can resist and construct new norms from their self-conducts.

This approach to power and the production of subjectivity informs Foucault's understanding of neoliberalism. Foucault (2008: 119) explains how neoliberals use an 'economic approach to human behaviour' (Becker, 1976), not just as a description of human conduct but also as a prescriptive tool to administer subjects to act as competitive entrepreneurs (Foucault, 2008: 146-7). The latter should supposedly regard their own lives as human capital to be allocated to a finite number of mutually exclusive ends on the basis of calculative cost-benefit analyses to maximize returns (Dardot and Laval, 2013: 106-7). The focus is on the production of subjects that enact entrepreneurial norms. This set-up renders the entrepreneur 'eminently governable' (Foucault, 2008: 270), but also allows its subjects free self-conduct (Bröckling, 2016: 44-5). It aims to steer this freedom toward an entrepreneurial lifestyle but is also exposed to counter-conducts (Lazzarato, 2009: 114; Death, 2010). Whenever a dispositif aims to steer subjects toward entrepreneurship, these subjects can demand to be governed differently (Lorenzini, 2018: 7-8). Neoliberal subjects can use their freedom to set up new norms, counter-practices, and counter-knowledges, as one witnesses in initiatives like the alter-globalization movement or Occupy Wall Street in 2011. Foucault's analysis of neoliberal power-relations is hence silent about exclusion. Its emphasis lies on how entrepreneurial subjects are produced, not on how subjects might be barred from these processes. He does not deny that neoliberal dispositifs might eject some subjects if entrepreneurialization would fail, but it is not the focus of his lectures. The same emphasis will be repeated in subsequent theories of neoliberal subject-formation.

\section{The Differential Management of Inequalities}

The reception of Foucault's silence about exclusion in contemporary theories of neoliberal subject-formation is threefold. Firstly, many theories of neoliberal subject-formation uncritically repeat Foucault's neglect of exclusion (McNay, 2009; Read, 2009; Dardot and Laval, 2013; Bröckling, 2016). Secondly, there is a group of thinkers that reinserts the notion of 'exclusion', but via Foucault's work (2003) on thanatopolitics and state racism (Mbembe, 2003; Esposito, 2008; Willse, 2010). State racism is a dispositif that identifies within the species-body of the population specific threats to its vitality and health, and wages a war against those threats to immunize the population from them (Raffnsöe et al., 2015: 220-1). Foucault (2008: 228) himself, however, denies that neoliberalism mobilizes racist strategies. Although neoliberal dispositifs identify threats to the prosperity of populations, they rarely phrase this in 
biological or race-related terms, nor do the power-relations they establish conform to the model of warfare, of which Foucault had grown sceptical after 1976 (Nigro, 2014: 130; Raffnsöe et al., 2015: 226). ${ }^{3}$ Another model would thus be more appropriate.

The third group provides such a model of exclusion more in line with Foucault's own approach to neoliberalism (Lazzarato, 2009; Mezzadra and Neilson, 2012; Brown, 2015; Newheiser, 2016). In his 1979 lectures Foucault himself focuses on how neoliberal dispositifs operationalize power-relations aimed at producing entrepreneurial subjects. To that purpose, he envisions not exclusion, but a 'theme-program of a society in which there is an optimization of systems of difference' (2008: 259). Within a competitive environment being different from one's peers generates profits (McNay, 2009: 58). Only by demonstrating that one's own enterprise is unique compared to others' can one attract potential investors. This promotion of inequality, however, manifests a dark side. 'When market competition becomes generalized as a social and political principle, some will triumph and some will die' (Brown, 2015: 64-5). Similarly to the 'abnormal' confined to psychiatric institutions, those who lose the competition do not become complete outsiders, but underperforming entrepreneurs in need of rehabilitation. Even an unemployed person is an entrepreneurial 'worker in transit' (Foucault, 2008: 139). His low human capital is the result of mistaken investment choices that demand re-education (Lazzarato, 2009: 111-12). For those deviating from social customs, there are consequently dispositifs 'to transform the "excluded" individual, the unemployed, the precarious worker, etc. into human capital, that is, techniques that mobilize the skills and subjectivity of the individual to adapt him/her for work opportunities' (Lazzarato, 2009: 127).

The division between 'winners' and 'losers' prescribes a differentiated treatment of entrepreneurs. Individuals with human capital in high demand can be largely left to self-govern. They will freely act in economically rational ways without much governmental steering. Individuals with propensities for non-lucrative investments, however, need more guidance. Just like the insane from Foucault's texts on psychiatry require professional rehabilitation, the entrepreneurs who make 'suboptimal' decisions should adjust their conduct, if not via governmental steering - for example, augmenting the tuition fees for the humanities - then through disciplinary techniques, such as self-management training for the unemployed (Dean, 2009: 159-60; Lazzarato, 2012: 94). Newheiser (2016: 7-8) highlights a helpful framework to distinguish these two treatments: disciplinary 'normation' (Foucault, 2007: 57) imposes a preconceived norm on individual subjects and forces 'abnormals' to conform to this standard. Biopolitical normalization, on the other hand, leaves the population to itself as long as statistical norms are optimal. Eccentrics are tolerated as long as they do not negatively affect the overall average. 
The social theory thusly portrayed does not assume a clear-cut opposition between inside and outside, but a selection machine that stratifies subjects in normalizing or normating dispositifs according to how promissory their human capital is. 'Inclusion and exclusion, the normal and the abnormal, do not determine a "great division"; they are instead variables of governmental action that tends, anyway, to multiply cases, situations or statuses' (Lazzarato, 2009: 119). Failed entrepreneurs are not excluded from the market, but are distributed to a different, more invasive regime that re-educates them (Lazzarato, 2015: 74).

One key example of the differential management of inequalities is debt. Since the 1970s, a patchwork of debt dispositifs has stratified populations according to the creditworthiness of individual subjects. The latter is measured through knowledge-gathering procedures expressed as credit scores like the FICO score (Joseph, 2014: 98-100). The credit scores constitute a selection machine that distributes individuals into different segments of creditworthiness, each with its own governing dispositif (Feher, 2017). Following Newheiser's distinction, creditworthy debtors are normalized biopolitically, while uncreditworthy debtors experience disciplinary normation. For the former, a narrative of risk-loving credit applies (Dardot and Laval, 2013: 275-8). Promising new ventures are encouraged to attract investments to push through innovations. Debt is in casu a means for the agile entrepreneur to finance activities with future earnings. It functions not as a disciplining institution geared to normate individuals toward more entrepreneurial ends, but as an instrument of empowerment. It consolidates entrepreneurial self-conducts already present. Less promising subjects experience the disciplinary side of debt (Lazzarato, 2012). Student loans, for example, aim to rationalize students' educational choices. Since higher education has been framed less as a civic service and more as a gateway to labour markets (Goodnight et al., 2014: 76), students are supposed to opt for degrees that promise further economic growth. Student loans are consequently a strategy to discipline students to choose fields that promise enough returns on investment to reimburse their debts. Uncreditworthy students encounter more authoritarian measures to make them reconsider their choices, like high additional collection charges, denial of access to future federal financial aid programs, reporting defaults to credit rating agencies, etc., to ensure reimbursement (Goodnight et al., 2014: 83).

In sum, the differential management of inequalities via neoliberal debt regimes reconfigures exclusion as a segmentation of the population. Knowledge-gathering devices like credit scores allot individuals to different categories according to their creditworthiness as entrepreneurs. Successful individuals are predominantly trusted to self-govern, whereas the disadvantaged receive disciplinary treatments via invasive debt management measures. Obviously, the production of neoliberal subjectivities via debt does not rule out the possibility of resistance (Graeber, 2010; 
Negri and Hardt, 2012; Lazzarato, 2015). Since debt dispositifs aim to entrepreneurialize subjects, the latter can subvert neoliberalism by cultivating counter-conducts. Movements like Occupy Wall Street, Debt Strike, Podemos, etc., configure alternative forms of government, such as debt strikes, the introduction of alternative currencies, egalitarian selfgovernment, etc., with the aim of escaping the forces that push them toward entrepreneurial lifestyles and configure new forms of life.

\section{Images of Abandonment}

The differential management of inequalities focuses on how neoliberal dispositifs apply entrepreneurializing norms in variegated ways without ever really excluding subjects from the aim of entrepreneurialization itself. I now turn to neoliberal regimes of practices that do not attempt to entrepreneurialize subjects, but withdraw themselves from these subjects. Following Agamben's (1998) conceptualization of abandonment, one would call such subjects 'included in the [neoliberal] order solely in the form of [their] exclusion' (Agamben, 1998: 8). Neoliberal dispositifs sometimes maintain themselves not by subjecting populations to their norms, but by emphatically suspending these norms for groups that harm the population's vitality. The model of differential management does not make this impossible, but neither does it consider this possibility explicitly. Allow me to put forward two illustrations:

(1) Between 2008 and 2011, the French telecommunications provider France Télécom experienced 69 suicides and 41 attempted suicides among its employees (Chabrak et al., 2016: 502). Many of these workers blamed France Télécom in their suicide notes or even committed the act in the workplace. After the privatization of the company in 1997, managerial priorities had shifted toward shareholder value maximization (Chabrak et al., 2016: 506-7). The company guaranteed high returns to investors, which implied downsizing the workforce, instead of providing qualitative services to consumers. Workers had, however, kept their labour protections from the civil service. France Télécom was hence unable to fire most employees (Waters, 2014: 130). Instead of downsizing, it forced workers to frequently relocate all over France, pushed staff into new functions they had no qualifications for or interest in, and used psychological pressure to undermine workers' sense of self-worth. The goal was to destabilize social ties in order to encourage workers to resign voluntarily, 'so that better statistics could be communicated' (Chabrak et al., 2016: 510). 'The objective of the enterprise [was] not to deliver high-quality work, but to make a maximum of employees resign' (Renou, 2010: 154; my translation). Although employees were increasingly subjected to evaluations and normating measures, these techniques did not serve to gather knowledge about or discipline the workforce, but to expel workers from the company's balance sheets. 
These mechanisms made individuals disappear from the population instead of producing entrepreneurial subjects. Except for the suicides themselves, there was hardly any resistance (Waters, 2015). The techniques normally associated with the neoliberalization of subjectivity, like establishing of competition or performance evaluations, here mostly served as a 'laboratory of antipathy' (Renou, 2010: 156) to encourage workers not to improve their productivity, but to leave the firm voluntarily. They cut social ties so that employees confronted their problems alone instead of collectively (Berardi, 2015: 171). These techniques repressed empathy among workers for each other's suffering, since solidarity would hinder an individual's own well-being in the firm. France Télécom eventually cultivated an anomic workplace conducive to suicide instead of the collective construction of alternative forms of life.

(2) Neoliberalism's aim of making the population productive via competition and entrepreneurialism is frequently measured in GDP improvements (Fioramenti, 2016). Just as corporations manage their statistics to attract shareholders, states need good GDP metrics in order to procure credit from bondholders on international capital markets (Streeck, 2017: 22-3; Feher, 2017: 86). As indicative of economic growth as this number may be, it ignores negative environmental side-effects (Fioramenti, 2016: 16). States consequently tend to transfer their environmental risks to other, disadvantaged regions in order to enjoy the productivity gains of increased economic activity without the damaging side-effects (Beck, 2009: 164). The result is a system of 'organized irresponsibility' (Beck, 2009: 91). Haina, for example, is a small city in the Dominican Republic that specializes in battery recycling and lead smelting (Sassen, 2014: 1678). These operations are vital to the Western 'green' economy, but are also very polluting. Western actors consequently outsource these activities to less visible areas. The result is an environmental and social calamity with over 90 per cent of Haina's children suffering from lead poisoning. Although GDP serves to make economic performance visible as a tool for population management, it also renders negative side-effects invisible. The statistics solely display advantages: Western states can 'green' their economies and the Dominican Republic gains GDP growth thanks to the added industrial productivity. The people of Haina, however, are evidently not the addressees of these measurements' call for entrepreneurial economies. They are abandoned to a poisoned life. To sustain entrepreneurial economies, states render the side-effects of pollution invisible by shifting them to populations that serve as collateral damage. In these circumstances, GDP is not a tool for information-gathering, but creates 'spaces of non-knowledge' (Beck, 2009: 172). It not only reveals certain phenomena, but also hides some. Economic activity engenders unintended and unpredictable risks, so it is purportedly better to locate those risks in sections of the global population that do not count. 
These examples cannot be explained by referring to non-neoliberal dispositifs (neo-colonialism, neo-conservatism, Keynesianism, etc.) that would have caused these hindrances to entrepreneurialization. What connects them is the presence of neoliberal dispositifs (corporate governance and GDP) without the subsequent production of entrepreneurial subjectivity. The model of differential management hence also seems inappropriate. Apparently there are neoliberal regimes of practices that make subjects and their social networks disintegrate by withdrawing knowledge-gathering devices and governmental steering. Also 'socially assigned disposability [...] proves fundamental to the neoliberal regime' (Butler and Athanasiou, 2013: 19-20). Following Agamben's conceptualization of abandonment, these subjects are held in a state of inclusive exclusion (1998: 7). Neoliberal regimes exert power over these populations not by subjecting them to entrepreneurial norms, but by suspending the application of these norms. They designate 'surplus populations' that have to be abandoned and rendered invisible so that these regimes can preserve themselves.

\section{Two Models of Exclusion}

The previous sections point to two operations of neoliberal dispositifs. One applies neoliberal norms to populations to entrepreneurialize them via a system of differential management, while the other suspends the application of these norms to expel them from the population (see Table 1).

The schematic presentation in Table 1 is obviously crude in comparison to concrete dispositifs, where one will often find hybrid cases of differential management and abandonment. Prison regimes have, for example, been described both as sites of disciplinary normation (Foucault, 1977; Joseph, 2014: 36-46) and of expulsion (Wacquant, 2009; Sassen, 2014: 63-5). Austerity measures in Greece are likewise simultaneously disciplinary enforcements of entrepreneurialism

Table I. Neoliberal dispositifs.

\begin{tabular}{|c|c|c|}
\hline & $\begin{array}{l}\text { Differential management } \\
\text { of inequalities }\end{array}$ & Abandonment \\
\hline Activity & $\begin{array}{l}\text { Differentially applying entrepre- } \\
\text { neurial norms }\end{array}$ & $\begin{array}{l}\text { Withdrawing the application of } \\
\text { entrepreneurial norms }\end{array}$ \\
\hline Aim & Producing subjects & Expelling subjects \\
\hline Knowledge & $\begin{array}{l}\text { Informs government about the } \\
\text { population }\end{array}$ & $\begin{array}{l}\text { Veils the existence of surplus } \\
\text { populations }\end{array}$ \\
\hline Resistance & Counter-conduct & $\begin{array}{l}\text { Existential absolutization of } \\
\text { inexistence }\end{array}$ \\
\hline
\end{tabular}


(Lazzarato, 2015: 38-9) and tricks to expel the poor from official statistics (Sassen, 2014: 2). Even a phenomenon as local as the 2013 UK Bedroom Tax (Gibb, 2015; Greenstein et al., 2016: Nowicki, 2017a, 2017b) can be described both as a means to discipline social tenants to move to private housing or as a justification to evict the poor and the disabled onto the streets and cut them out of government spending records. There is no reason to choose one approach over the other (Butler and Athanasiou, 2013: 30-1). One could compare it to the study of an impressionistic painting like Monet's Water Lilies. From a distance the lilies can clearly be distinguished from the water. The boundaries between two separate beings are visible. However, when one looks closer, this certainty dissolves and borders become more fluid. Some individual brush strokes still clearly belong to one entity, but some are not easily classifiable as part of the lilies or the water. Although one can look at them from the perspective of either the lilies or the water, in themselves the brush strokes display characteristics of both simultaneously. Likewise the heuristic distinction between differential management and abandonment is clear from a distance but dissolves in some individual cases.

In the first model, neoliberalism operates via variegated dispositifs of entrepreneurialization. The aim is not to deny membership to the 'excluded', but to engender the behavioural conditions of possibility for neoliberal subjectivity. People have to learn to become entrepreneurs of oneself - some the hard way. Governments hence require extensive information on the population and individual subjects, like credit-scoring technologies, in order to steer them efficaciously toward entrepreneurship. The presupposed freedom of the governed, however, leaves room for resistance as counter-conducts, since they can reject neoliberal governmentality and demand to be governed differently.

The model of abandonment is likewise grounded in neoliberal dispositifs like corporate governance and GDP measurements, but the aim is not to educate people into becoming entrepreneurs but to expel them from the governed population. At France Télécom workers are not pressured into performing neoliberal subjectivities. Entrepreneurial norms are emphatically not applied, since the aim is no longer to make them into productive employees but to make them disappear from the firm's quarterly reports. These regimes do not gather information on the population useful for governmental steering but try to eliminate individuals from the data about the population. At France Télécom, individual monitoring and continuous evaluations did not produce information useful for maximizing productivity but encouraged workers to resign.

The collective capacities for constructing counter-conducts are also limited. When subjects are abandoned, governmental instances do not care to entrepreneurialize them but to eject them from the governed population. There are hence no specific norms to resist. The immediate 
problem for the abandoned is, on the contrary, that they are not recognized as subjects worthy of being governed. The only somewhat efficacious form of resistance to such a condemnation to invisibility is to force one's existence onto governmental recognition. Prozorov (2014: 9) calls this, with Badiou in mind, "the "existential absolutization of the inexistent": what was nothing in the world, what was proscribed from appearance despite its being, comes not merely to occupy some (minor) place in the world but is endowed with maximal existence.' Riots, for example, mainly combat the invisibility to which the disadvantaged are fated with violent outbursts that create an excessively visible spectacle out of one's own existence (Ehrenberg, 1991: 45-65; Tyler, 2013: 39-41; Sutterlüty, 2014). One member of the 2011 London riots phrases it succinctly: 'When no one cares about you you're gonna eventually make them care, you're gonna cause a disturbance' (Guardian \& LSE, 2011: 25). A participant at the 2005 French riots concurs: 'I burned some cars near the high school to show that we exist' (Sutterlüty, 2014: 47). Also the France Télécom workers' suicides and attempts at self-immolation (Waters, 2014: 125; 2015) emphatically show that they exist, even if neoliberal dispositifs attempt to render them non-existent. They do not want to be governed differently but they demand visibility as subjects worthy of government. They wish to escape not the application of entrepreneurial norms but their suspension. In Rancièrian terminology (Rancière, 2010: 36-7; Tyler, 2013: 171-6): as the part that has no part (la part des sans-parts) in government, their resistance effectuates a redistribution of the sensible so that they too can be counted as members of the population. ${ }^{4}$

My point is not that the theory of differential management of inequalities is wrong but that the theory of neoliberal subject-formation has until now disproportionately focused on one kind of exclusion, which has left abandonment understudied. The latter exemplify the emphatic non-production of entrepreneurial subjects within neoliberal dispositifs. The possibility of a withdrawal of norms as a means to exert power (Agamben, 1998: 20) is underemphasized in the study of the production of neoliberal subjectivities. Agamben argues that power can operate by suspending interventions in the population. For instance, legal power not only works by applying juridical rules to particular cases but also by declaring the state of exception, i.e. by suspending the applicability of the law and abandoning individuals to arbitrary police violence without legal guidance. Neither Agamben nor Foucault, however, is very helpful in trying to unravel how the suspension of norms has become a strategy for neoliberal dispositifs. Agamben has never written a monograph explicitly about neoliberalism while Foucault's lectures do not address the issue of abandonment. I propose instead to use Saskia Sassen's (2014) research on financialization and expulsion to localize the role of abandonment in neoliberalism. 


\section{Finance and the Expulsion of Surplus Populations}

Sassen emphasizes how the financialization of the economy since the 1980s parallel to the advent of neoliberalism has propelled the expulsion of 'surplus populations' (Sassen, 2016: 90). The latter are groups from which wealth has been extracted until they are no longer profitable and are subsequently expelled as an obstacle to further economic growth. Neoliberal dispositifs no longer aim to entrepreneurialize these groups, since their presence constitutes a drag on profits. These are not the sinners against the commandments of entrepreneurialism who have to be re-educated through disciplinary normation, but people deemed too costly for growth. 'They did not sin, though they have merit that is not enough' (Dante, Inferno IV.34-35). The surplus population might have the potential to lead an entrepreneurial life, but there are no shareholders willing to invest in the actualization of that potential. Shareholders consequently withdraw their demands for entrepreneurializing this population. Financialization inserts strategies of abandonment into neoliberalism in two ways: (a) the dominance of shareholder value over governments and corporations and (b) the imitation of finance's growth-model outside the financial sector.

(a) Since the 1970s and ' $80 \mathrm{~s}$ governments and corporations have become increasingly dependent on financial credit and thus on a reputation of creditworthiness. They 'appear to be increasingly concerned about pleasing the financial markets rather than setting goals for social and economic well-being' (Sassen, 2006: 262). The discourse on shareholder value justifies this shift (Jensen and Meckling, 1976; Fama and Jensen, 1983). If individuals are indeed utility-maximizing calculative entrepreneurs, economists worry about the separation between shareholders' ownership and managers' control over corporate assets. The risk is that managers would selfishly use these assets to their own advantage instead of procuring added value for shareholders (Friedman, 1970). Since shareholders are corporations' owners, the profits should purportedly go primarily to dividends and stock buyouts, not to wages or reinvestments (Lazonick and O'Sullivan, 2000). If the principals are thus to maintain their grip on the corporation's operations, they have to align their agents' preferences to their own. By linking, for instance, personal remuneration to financial performance standards, investors are able to change managers' priorities toward maximizing shareholder value.

Since then, shareholder value has been associated with a particular set of business practices, including the introduction of financial performance measures such as return on equity, the adoption of international accounting standards, and a short-term business 
outlook as manifested by the publication of quarterly reports. (Van

Der Zwan, 2014: 107-8)

When applied to states, the ultimate citizens are consequently the state's bondholders, not the electorate (Streeck, 2017; Vogl, 2017). Whether a government can, for instance, introduce a welfare policy depends largely on its impact on the nation's creditworthiness and thus on its reputation with investors.

Economic citizenship does not belong to citizens. It belongs to firms and markets, particularly the global financial markets, and it is located not in individuals, not in citizens, but in global economic actors. (Sassen, 1996: 43)

They vote via their investment portfolios (Feher, 2017: 88) and determine thereby which lives are worthy of being entrepreneurialized and which should better be abandoned for lack of promising investment opportunities. The people who see their living conditions deteriorate are the collateral damage of shareholder prosperity (Moulier Boutang, 2011: 142). They are the 'excess human capital' (Ho, 2009: 237) corporations and governments have to abandon in order to grow. The dispositifs aimed at procuring shareholder value hence produce surplus populations, i.e. people whose existence is no longer profitable in terms of shareholder value and consequently have to disappear from official statistics to maintain a creditworthy image. Governmental instances thus restrict the applicability of neoliberal norms to keep up the reputation of creditworthiness, even if that means that some people are expelled from neoliberal entrepreneurialization. France Télécom, for example, had taken on large amounts of debt, which obliged it to urgently increase its shareholder value. It had to prove its financially promissory image by maintaining a lean labour force. The 'management by terror' that subsequently ensued is hence the consequence of pro-shareholder attitudes influencing corporate strategies.

Since governments and firms have to maintain creditworthy status in the eyes of shareholders, they reorient the purpose of their informationgathering tools. The latter become means to render unproductive sections of the population invisible. In the differential management model, evaluation and surveillance techniques reveal the truth about the population, which governments subsequently use to entrepreneurialize their self-conduct. Sassen argues the same metrics do not only expose but also veil economic realities. Metrics like GDP render the expulsions under neoliberalism invisible by ejecting relevant phenomena from their measurements, as in the Haina case. GDP-centric documents published by national governments provide capital markets with data that does not reflect the actual state of the whole population, but only the information 
that sustains a creditworthy image. They project an over-optimistic picture for bondholders by disregarding negative externalities. Instead of an attempt at rehabilitation,

there is a de facto redefinition of 'the economy' when sharp contractions are gradually lost to standard measures. The unemployed who lose everything - jobs, homes, medical insurance - easily fall off the edge of what is defined as 'the economy' and counted as such. [...] The expelled become invisible to formal measurements, and thereby their negative drag on growth rates is neutralized. (Sassen, 2014: 36-7)

Metrics supposed to express economic growth hence easily conceal human suffering.

(b) Financialization not only regards the increased power of financial markets and the investment public, but also the extension of its business strategy to non-financial sectors where new surplus populations are created. According to Sassen (2010), financial accumulation repeats the practices of primitive accumulation Marx described in 16th- and 17th-century England (1977: 667-85) in a more abstract fashion. Both extract wealth from external sources and discard the population that initially generated this wealth. Finance allegedly expropriates populations from their wealth and privatizes the latter within the financial sector. Financial value parasitizes on non-financial wealth-creation. Sassen (2014: 121-33; 2016) gives the example of the US mortgage market. Before the housing boom, there were only masses of illiquid household savings. During the 1980s, when wages stagnated and welfare institutions were defunded, households were encouraged to use their household savings as investment instruments (Mian and Sufi, 2015: 75-80). Especially real estate was praised as a promising substitute for declining wages. Households consequently used their savings as collateral for mortgage loans, which mobilized these assets for the financial economy as promises to repay mortgage debt. Financial firms generated profits primarily through trade in these products. 'The source of profit for the investor is not the payment of the mortgage itself, but the sale of the financial package that bundles hundreds or thousands of mortgage slices' (Sassen, 2014: 124-5). Of course, this rent remained in the financial sector and did not go to the households themselves, whose creditworthiness constituted the underlying asset for these products. The population's non-financial wealth in savings was mobilized for the private rent-collection of financial corporations. Once all added value was extracted from American savings and the household debt market crashed, these households became a disposable surplus population to further financial growth and could hence be expelled.

The same scheme has migrated to other industries (Moulier Boutang, 2011; Sassen, 2018: 127). Internet companies like Google or Facebook, 
for example, generate rent by amassing data about their consumers and selling that to advertisers (Marazzi, 2011: 51-7). A wealth of information outside the capitalist system is first captured and then privatized. Also the rise of immaterial labour points in the direction of primitive accumulation (Negri and Hardt, 2009: 138-42). Communicative and affective skills are generated outside the workplace but have become productive factors of which the benefits go to private enterprises. Immaterial labour, however, requires psychic investments from workers who have only a limited supply of attention. They have to be reachable $24 / 7$ for their employers via email or cell phones, procure and maintain a social network, be continuously creative, etc. (Berardi, 2009: 90). Once the employees' psychic energy is depleted, they become at risk of suffering from depression, burnout, or other symptoms of work-related stress (Ehrenberg, 1991: 271; Micali, 2010; Bröckling, 2016: 200-1). Instead of adding value to the corporations who privatize their social and affective investments, their lack of immaterial productivity becomes an obstacle to further growth. Large portions of the contemporary workforce can no longer adjust to the entrepreneurial work rhythm and subsequently become a burden to their employers. Under these circumstances, a corporation's most rational course of action seems to be to expel these exhausted workers from the workforce (Berardi, 2012: 76-7). Corporations hence impose entrepreneurial norms on their workers until the latter are no longer capable of conforming to these norms. Then the strategy switches to expelling depressed workers from corporate balance sheets. The diffusion of financial accumulation hence accelerates the production of surplus populations. Not only financial ventures but also non-financial firms simply extract value from outside sources until there is nothing left. Afterwards they abandon these populations.

Concerning the possibility of resistance, Sassen is pessimistic. 'As conditions become acute, [the organizing logic's instruments] contribute to a [condition] marked by expulsions - from life projects and livelihoods, from membership, from the social contract at the centre of liberal democracy' (Sassen, 2014: 29). She consequently remains silent about the prospects of resistance against abandonment and the forms such resistance might take (Kennedy, 2015: 13-14). Here as well, resistance can be conceptualized as the existential absolutization of the inexistent. Surplus populations do not demand to be governed differently, because they are expelled from governmental interventions. Instead, their practices aim to demand visibility and claim existence (Butler and Athanasiou, 2013: 101). The most extreme attempt at breaking the ruling distribution of the sensible is suicidal violence (Berardi, 2015: 50), but riots, hooliganist vandalism, or voting for extremist parties (Sassen, 2018: 130) could also be signs of forgotten populations forcing governments to acknowledge their existence. 


\section{Conclusion}

Foucault's lectures on The Birth of Biopolitics have been a tremendous influence on contemporary studies of neoliberalism. They have, however, had a one-sided impact on the study of the role of exclusion in neoliberal subject-formation. Foucault had rejected the terminology of 'exclusion' for being too abstract to account for the multifarious regimes of practices that generate these so-called exclusions and for suggesting an unrealistic inclusion/exclusion-dichotomy. The 1979 lectures consequently focus on how neoliberal dispositifs entrepreneurialize subjects and not on how individuals become excluded from entrepreneurialization. The focus on the variegated forms of applying entrepreneurial norms has persisted in the theory of neoliberal subject-formation. It has developed into a reinterpretation of exclusion according to the model of differential management of inequalities: neoliberal dispositifs stratify the population according to how successfully people conduct their lives as entrepreneurs and normate those deemed unsuccessful. Debt regimes, for example, encourage promising entrepreneurs to take on risk and generate new profitable futures, while disciplining the individuals who maintain less creditworthy lifestyles. Resistance against neoliberalism here takes the form of counter-conducts, i.e. behaviours that escape entrepreneurialization in favour of new norms.

I have shown that the notion of exclusion as abandonment should be added to the differential management model to illuminate the role of exclusion in neoliberal subject-formation. There are cases where neoliberal regimes of practices do not apply entrepreneurial norms on populations - whether through normalization or normation - but suspend the application of entrepreneurial norms in order to abandon populations deemed unproductive for further economic growth. In these instances, resistance is less likely and takes the form of an existential absolutization of inexistence. The abandoned demand in a spectacular fashion to regain visibility as full members of society. The decision over what parts of the population are fit for entrepreneurialization and what parts should be expelled can be traced, with Sassen, to the rise to power of financial markets and their model of accumulation based on extraction and expulsion of surplus populations - a development Foucault could not have predicted in 1979. Financialization, firstly, makes corporations and governments dependent on the approval of financial agents to attract capital, which incentivizes the expulsion of groups that trouble statistics, while secondly, it encourages financial and non-financial firms to extract value from populations until the latter's resources are depleted and should be abandoned.

\section{Acknowledgements}

I wish to thank my colleagues at RIPPLE, KU Leuven, and at the Critical Finance Studies Conference at Leicester to whom I have 
presented this work. I also wish to thank the people at the Monitoraat for providing me with the warm and welcoming atmosphere necessary for creative and fulfilling work.

\section{Notes}

1. They do not deny the existence of non-entrepreneurial forms of subjectivity within neoliberalism. Mezzadra and Neilson (2013: 174-5) show how sovereign power produces necropolitical subjects in neoliberal border regimes. This, however, locates the forces of exclusion outside of governmentality in another power regime, sovereignty, that intersects with neoliberal governmentality. Dean (2009: 187-92) and Dardot and Laval (2013: 309-10), on the other hand, acknowledge the production of neo-conservative subjectivities that justify disciplinary interventions within populations that fail to adhere to entrepreneurial norms.

2. Sassen derives the term 'surplus population' from Marx's study on primitive accumulation (1977: 667-85) not because it is subject to the same kind of immediate concrete violence as the populations Marx studied, but because its genesis stems from a similar mode of accumulation (extraction and expulsion) that Marx located in the enclosures movement, and Sassen sees returning in the abstract realm of finance (see infra). This, however, does not exclude the existence of instances of primitive accumulation in Marx's original sense.

3. Although many of the occurrences of state racism are better explained with non-neoliberal subjectivities like neo-conservatism (see note 1), Ashurst and Venn (2014: 163-71) question Foucault's dismissal of state racism. They show how neoliberal education reforms in the UK have substituted the entrepreneurialization of children for the mere disciplinary punishing of poor and racialized children without the aim to foster productive subjects. The main goal is to set an example and immunize the school population from these 'bad apples' by keeping them out. Delving deeper into this phenomenon, however, deserves a study of its own.

4. There is more to be said about the different forms of existential absolutization of inexistence. I do not, for instance, answer why in some cases this expresses itself as riots or populist upsurges, while in other instances as mass suicides. This would, however, take the argument too far away from the initial question, being the role of exclusion in neoliberal subjectformation.

\section{References}

Agamben G (1998) Homo Sacer: Sovereign Power and Bare Life. Stanford: Stanford University Press.

Allen A (2013) Power and the subject. In: Falzon C, O'Leary T and Sawicki J (eds) A Companion to Foucault. Chichester: Wiley-Blackwell, pp. 337-352.

Ascher I (2016) Portfolio Society: On the Capitalist Mode of Prediction. New York: Zone Books.

Ashurst F and Venn C (2014) Inequality, Poverty, Education: A Political Economy of School Exclusion. London: Palgrave Macmillan.

Beck U (2009) World at Risk. Cambridge: Polity Press. 
Becker G (1976) The Economic Approach to Human Behavior. Chicago: University of Chicago Press.

Berardi 'Bifo' F (2009) The Soul at Work. Los Angeles: Semiotext(e).

Berardi 'Bifo' F (2012) The Uprising: On Poetry and Finance. Los Angeles: Semiotext(e).

Berardi 'Bifo' F (2015) Heroes: Mass Murder and Suicide. London: Verso Books.

Bröckling U (2016) The Entrepreneurial Self. London: SAGE.

Brown W (2015) Undoing the Demos: Neoliberalism's Stealth Revolution. New York: Zone Books.

Butler J and Athanasiou A (2013) Dispossession: The Performative in the Political. Cambridge: Polity Press.

Castel R (2009) La montée des incertitudes. Travail, protections, statut de l'individu. Paris: Editions du Seuil.

Chabrak N, Craig R and Daidj N (2016) Financialization and the employee suicide crisis at France Telecom. Journal of Business Ethics 139(3): 501-515.

Dardot P and Laval C (2013) The New Way of the World. London: Verso Books.

Davidson A (2011) In praise of counter-conduct. History of the Human Sciences 24(4): 25-41.

Davies W (2017) The Limits of Neoliberalism: Authority, Sovereignty and the Logic of Competition. London: SAGE.

Dean M (2009) Governmentality: Power and Rule in Modern Society. London: SAGE.

Death C (2010) Counter-conducts: A Foucauldian analytics of protest. Social Movement Studies 9(3): 235-251.

Ehrenberg A (1991) Le culte de performance. Paris: Callman-Levy.

Elden S (2016) Foucault's Last Decade. Cambridge: Polity Press.

Elden S (2017) Foucault: The Birth of Power. Cambridge: Polity Press.

Esposito R (2008) Bios: Biopolitics and Philosophy. Minneapolis: University of Minnesota Press.

Fama E and Jensen M (1983) Separation of ownership and control. Journal of Law and Economics 26(2): 301-325.

Feher M (2017) Le Temps des Investis. Paris: La Découverte.

Fioramonti L (2016) A post-GDP world? Rethinking international politics in the 21st century. Global Policy 7(1): 15-24.

Foucault M (2000) The subject and power. In: Foucault M (ed.) Power: Essential Works of Foucault, 1954-1984, Vol. 3. New York: The New Press, pp. 326-348.

Foucault M (2007) Security, Territory, Population. Basingstoke: Palgrave Macmillan.

Foucault M (2008) The Birth of Biopolitics. London: Macmillan Publishers.

Foucault M (2015) The Punitive Society. Basingstoke: Palgrave Macmillan.

Friedman M (1970) The social responsibility of business is to increase its profits. New York Times Magazine, 13 September.

Gibb K (2015) The multiple policy failures of the UK bedroom tax. International Journal of Housing Policy 15(2): 148-166.

Goodnight T, Hingstman D and Green S (2014) The student debt bubble: Neoliberalism, the university, and income inequality. Journal of Cultural Economy 8(1): 75-100. 
Gordon C (2013) History of madness. In: Falzon C, O'Leary T and Sawicki J (eds) A Companion to Foucault. Chichester: Wiley-Blackwell, pp. 84-103.

Graeber D (2010) Debt: the First 5,000 Years. Brooklyn: Melville House.

Greenstein A, Burman E, Kalambouka A and Sapin K (2016) Construction and deconstruction of 'family' by the 'bedroom tax'. British Politics 11(4): 508-525.

Guardian and LSE (2011) Reading the Riots. London: Guardian and London School of Economics and Political Science.

Hardt M and Negri A (2000) Empire. Cambridge, MA: Harvard University Press.

Hardt M and Negri A (2009) Commonwealth. Cambridge, MA: Belknap Press. Hardt M and Negri A (2012) Declaration. New York: Argo-Navis.

Ho K (2009) Liquidated: An Ethnography of Wall Street. Durham: Duke University Press.

Jensen M and Meckling W (1976) Theory of the firm: Managerial behavior, agency costs and ownership structure. Journal of Financial Economics 3: $305-360$.

Joseph M (2014) Debt to Society. Minneapolis: University of Minnesota Press.

Kennedy M (2015) Centering the edge in the shift from inequality to expulsion. Contemporary Sociology 44(1): 11-14.

Lazonick W and O'Sullivan M (2000) Maximizing shareholder value: A new ideology for corporate governance. Economy \& Society 29(1): 13-35.

Lazzarato M (2009) Neoliberalism in action: Inequality, insecurity and the reconstitution of the social. Theory, Culture \& Society 26(6): 109-133.

Lazzarato M (2012) The Making of the Indebted Man. Los Angeles: Semiotext(e).

Lazzarato M (2015) Governing by Debt. Los Angeles: Semiotext(e).

Lenoir R (1974) Les Exclus. Paris: Seuil.

Lorenzini D (2018) Governmentality, subjectivity, and the neoliberal form of life. Journal for Cultural Research 22(2): 154-166.

Lorey I (2015) State of Insecurity: Government of the Precarious. London: Verso Books.

Marazzi C (2011) The Violence of Financial Capitalism. Los Angeles: Semiotext(e).

Marx K (1977) Capital: A Critique of Political Economy (Volume I). London: Lawrence \& Wishart.

Mbembe A (2003) Necropolitics. Public Culture 15(1): 11-40.

McNay L (2009) Self as enterprise. Theory, Culture \& Society 26(6): 55-77.

Mezzadra S and Neilson B (2012) Between inclusion and exclusion: On the topology of global space and borders. Theory, Culture \& Society 29(4-5): $58-75$.

Mezzadra S and Neilson B (2013) Border as Method: Or, the Multiplication of Labour. Durham: Duke University Press.

Mian A and Sufi A (2015) House of Debt: How They (and You) Caused the Great Recession, and How We Can Prevent It from Happening Again. Chicago: University of Chicago Press.

Micali S (2010) The capitalistic cult of performance. Philosophy Today 54(4): 379-391.

Moulier Boutang Y (2011) Cognitive Capitalism. Cambridge: Polity Press. 
Newheiser D (2016) Foucault, Gary Becker and the critique of neoliberalism. Theory, Culture \& Society 33(5): 3-21.

Nigro R (2014) From Reason of State to Liberalism: The Coup d Etat as Form of Government. In: Lemm C. and Vatter M. (eds) The Government of Life: Foucault, Biopolitics, and Neoliberalism. New York: Fordham University Press, pp. 127-140.

Nowicki M (2017) A Britian that everyone is proud to call home? The bedroom tax, political rhetoric and home unmaking in UK housing policy. Social \& Cultural Geography, Available at: https://pure.royalholloway.ac.uk/portal/ files/28419429/A_Britain_that_Everyone_is_Proud_to_Call_Home.pdf (accessed 20 November 2018).

Prozorov S (2014) Theory of the Political Subject: Void Universalism II. London: Routledge.

Raffnsöe S, Gudmand-Höyer M and Thaning M (2016) Michel Foucault: A Research Companion. London: Palgrave Macmillan.

Rancière J (2010) Dissensus. London: Bloomsbury Academic.

Read J (2009) A genealogy of homo-economicus: Neoliberalism and the production of subjectivity. Foucault Studies 6: 25-36.

Renou G (2010) Les laboratoires de l'antipathie: À propos des suicides à France Télécom. La Revue du MAUSS 35(1): 151-162.

Sassen S (1996) Losing Control?: Sovereignty in the Age of Globalization. New York: Columbia University Press.

Sassen S (2006) Territory, Authority, Rights: From Medieval to Global Assemblages. Princeton: Princeton University Press.

Sassen S (2010) A savage sorting of winners and losers: Contemporary versions of primitive accumulation. Globalizations 7(1-2): 23-50.

Sassen S (2014) Expulsions. Cambridge, MA: Belknap Press.

Sassen S (2016) Predatory formations dressed in Wall Street suits and algorithmic math. Science, Technology \& Society 22(1): 6-20.

Sassen S (2018) Finance is an extractive sector: Interview with Saskia Sassen. In: De Cauwer S (ed.) Critical Theory at a Crossroads: Conversations on Resistance in Times of Crisis. New York: University of Columbia Press, pp. 113-133.

Streeck W (2017) Buying Time: The Delayed Crisis of Democratic Capitalism. London: Verso Books.

Sutterlüty F (2014) The hidden morale of the 2005 French and 2011 English riots. Thesis Eleven 121(1): 38-56.

Tyler I (2013) Revolting Subjects: Social Abjection and Resistance in Neoliberal Britain. London: Zed Books.

Van Der Zwan N (2014) Making sense of financialization. Socio-Economic Review 12(1): 99-129.

Vogl J (2017) The Ascendancy of Finance. Cambridge: Polity Press.

Wacquant L (2009) Punishing the Poor: The Neoliberal Government of Social Insecurity. Durham: Duke University Press.

Waters S (2014) A capitalism that kills: Workplace suicides at France Télécom. French Politics, Culture, and Society 32(3): 121-141.

Waters S (2015) Suicide as protest in the French workplace. Modern \& Contemporary France 23(4): 491-510. 
Willse C (2010) Neo-liberal biopolitics and the invention of chronic homelessness. Economy and Society 39(2): 155-184.

Tim Christiaens is a $\mathrm{PhD}$ researcher at the Institute of Philosophy, KU Leuven, Belgium. His work centres around theories of governmentality and neoliberalism in Foucault and Italian theory (Agamben, Lazzarato, Esposito, etc.). He has published in journals such as Philosophy and Social Criticism, Rethinking Marxism, and Epoché. 